\title{
Konsepsi Siswa Kelas XI IPA Negeri 5 Palangka Raya Tentang Senyawa Hidrokarbon Tahun Ajaran 2018/2019
}

\author{
Recka Susanti, Abdul Hadjranul Fatah, Sri Wahyutami
}

Program Studi Pendidikan Kimia, FKIP, Universitas Palangka Raya, Indonesia E-mail: yona123anthika@gmail.com

\begin{abstract}
ABSTRAK
Penelitian merupakan penelitian deskriptif, dilaksanakan di SMA Negeri 5 Palangka Raya pada 80 siswa di kelas XI IPA-1 SMA Negeri 5 Palangka Raya Tahun ajaran 2018/2019. Data penelitian didapat melalui tes uraian siswa dan wawancara siswa. Hasil penelitian menunjukkan bahwa rata-rata kosepsi siswa tertinggi terletak pada konsepsi siswa tantang pengertian senyawa hidrokarbon yaitu sebesar $63,75 \%$ dan berada pada kategori tuntas. Konsepsi siswa tentang memberikan nama senyawa hidrokarbon alkana, alkena dan alkuna ialah 34,6\% siswa masuk kategori tidak mengerti. Konsepsi siswa tentang membedakan atom C primer, sekunder, tersier dan kuartener ialah 33,125\% masuk kategori tuntas dan konsepsi siswa terendah tentang mengelompokan senyawa hidrokarbon berdasarkan kejenuhan ikatan ialah 30\% siswa masuk kategori tuntas. Penguasaan konsepsi siswa terbagi kedalam (empat) kategori yaitu tidak mengerti, tuntas sebagian, mendekati tuntas dan tuntas. Banyak siswa menjawab dengan benar pengertian senyawa hidrokarbon dan menjawab dengan benar perbedaan atom $\mathrm{C}$ primer, sekunder, tersier dan kuartener. Banyak siswa tidak mampu menjawab dengan benar mengelompokan senyawa hidrokarbon berdasarkan kejenuhan ikatan dan memberikan nama pada senyawa hidrokarbon.
\end{abstract}

Kata Kunci: konsepsi, senyawa hidrokarbon, tes uraian

\section{Pendahuluan}

Ilmu kimia merupakan mata pelajaran yang memiliki karakteristik tersendiri dan keterampilan dalam memecahkan masalah-masalah berupa fakta, konsep, hukum dan teori yang berhubungan dengan komposisi, struktur, sifat dan perubahan energi (Depdikbud, 1999). Konsep dalam ilmu kimia merupakan konsep berjenjang, berkembang dari konsep-konsep sederhana menuju konsepkonsep yang lebih kompleks (Dahar, 1991).

Pembelajaran kimia ditujukan untuk membangun kompetensi antara lain kompetensi penguasaan konsep dan kompetensi kerja ilmiah. Hasil belajar kimia bukan hanya dalam bentuk pengetahuan (yang berupa fakta, konsep, prinsip, dan 
teori), tetapi harus mampu mengembangkan proses inkuiri dan pembentukan sikap. Beberapa kompetensi hasil pembelajaran kimia tercantum dalam kurikulum diantaranya adalah kemampuan untuk merancang dan melakukan penemuan ilmiah, memformulasikan penjelasan ilmiah dari hasil penemuan serta dapat mengkomunikasikan secara efektif hasil penemuan ilmiah.

Penelitian ini fokus pada hasil belajar siswa dari proses pembelajaran yang guru berikan sebelumnya. Peneliti mengumpulkan informasi dan menggambarkan bagaimana penguasaan konsep siswa dari proses pembelajaran di sekolah dengan pemberian tes tanpa diberikan suatu perlakuan terhadap subjek penelitian. Inilah yang menjadi perhatian peneliti, dimana pada penelitian ini peneliti merekonstruksi kembali proses pembelajaran yang guru berikan khususnya pada materi senyawa hidrokarbon.

Materi senyawa hidrokarbon terdiri dari beberapa indikator yaitu, mampu menjelaskan pengertian senyawa hidrokarbon, mengelompokan senyawa hidrokarbon berdasarkan kejenuhan ikatan dan tata namanya, memberi nama senyawa hidrokarbon (alkana, alkena, alkuna), dan membedakan atom $\mathrm{C}$ primer, sekunder, tersier, dan kuartener.

Bertolak dari paparan tersebut, dalam penelitian ini penulis mengambil judul "Konsepsi Siswa Kelas XI IPA I dan IPA II SMA Negeri 5 Palangkaraya Terhadap Senyawa Hidrokarbon.”

\section{Metodologi Penelitian}

Penelitian ini dilaksanakan penelitian ini adalah Siswa kelas XI IPA 1 dan siswa kelas XI IPA II SMA Negeri 5 Palangka Raya yang berjumlah 80 orang 
yang telah mempelajari materi senyawa hidrokarbon. Pengambilan data dilakukan pada kelas XI IPA 1 tanggal 14 dan pengambilan data kelas XI IPA II tanggal 15 Mei 2019.

Teknik analisis data dalam penelitian ini adalah data tes uraian konsepsi siswa tentang senyawa hidrokarbon yang dianalisis secara deskriptif dengan langkah-langkah sebagai berikut:

1. Jawaban siswa dikoreksi dan dikategorikan dalam kategori konsepsi sesuai tabel 1.

Tabel 1. Kategori Konsepsi

Kategori Kriteria Skor

Konsepsi

\begin{tabular}{llll} 
Tidak Mengerti & Tidak menjawab, tidak mengetahui, dan tidak & 0 \\
(TM) & $\begin{array}{l}\text { memahami. Mengulang sebagian atau seluruh } \\
\text { pertanyaan. Jawaban/respon tidak jelas atau tidak } \\
\text { relevan. Dijawab salah atau tidak logis. }\end{array}$ & \\
\hline $\begin{array}{l}\text { Tuntas } \\
\text { Sebagian (TS) }\end{array}$ & $\begin{array}{l}\text { Menjawab minimal dengan satu komponen yang sesuai } \\
\text { dengan konsep ilmiah }\end{array}$ & 1 \\
\hline Mendekati & $\begin{array}{l}\text { Dapat menjawab/merespon dengan benar beberapa } \\
\text { Tuntas (MT) }\end{array}$ & 2 \\
\hline jawaban minimal dua komponen & & \\
\hline & $\begin{array}{l}\text { Dapat menjawab/merespon semua komponen jawaban } \\
\text { yang telah ditentukan. }\end{array}$ & 3 \\
\end{tabular}

Kriteria tersebut serupa dengan yang digunakan oleh Morgil (2006), dan Dahromi (2016), yaitu denganmengkategorikan jawaban tes dengan kategori konsepsi seperti disajikan pada tabel 2.

Tabel 2. Kategori konsepsi Abraham et al.

\begin{tabular}{ll}
\hline \multicolumn{1}{c}{ Kategori } & \multicolumn{1}{c}{ Konsepsi } \\
\hline $\begin{array}{l}\text { Tidak mengerti (no } \\
\text { understanding) NU }\end{array}$ & $\begin{array}{l}\text { Tidak menjawab, tidak mengetahui, dan tidak } \\
\text { memahami. Mengulang sebagian atau seluruh } \\
\text { pertanyaan. } \\
\text { jawaban/respon tidak jelas atau tidak relevan. }\end{array}$ \\
\hline $\begin{array}{l}\text { Konsepsi alternative (specific } \\
\text { miskonseption) SM }\end{array}$ & $\begin{array}{l}\text { Dijawab salah atau tidak logis } \\
\text { Sebagian konsep (partial } \\
\begin{array}{l}\text { understanding with specific } \\
\text { misconception) UM }\end{array}\end{array}$ \\
\hline
\end{tabular}




\begin{tabular}{ll}
\hline $\begin{array}{l}\text { Mendekati konsepsi ilmiah } \\
\text { (partial understanding) PU }\end{array}$ & $\begin{array}{l}\text { Dapat menjawab/merespon benar beberapa } \\
\text { jawaban tetapi tidak semua komponen bias } \\
\text { dijawab }\end{array}$ \\
\hline $\begin{array}{l}\text { Konsepsi Ilmiah (sound } \\
\text { understanding) SU }\end{array}$ & $\begin{array}{l}\text { Dapat menjawab/merespon semua komponen } \\
\text { jawaban yang telah ditentukan }\end{array}$ \\
\hline
\end{tabular}

Kriteria penilaian disarankan oleh Abraham et al. (1994) dalam Calik (2005). Kategori konsepsi yang dipakai ditabel 4 akan di setarakan pada kategori konsepsi menurut Abraham et al. (1994) dalam Calik (2005). Kriteria konsepsi NU dan SM akan di setarakan dengan kategori konsepsi tidak mengerti (TM), kategori konsepsi UM disetarakan dengan kategori konsepsi tuntas sebagian (TS), kategori konsepsi PU akan disetarakan dengan kategori konsepsi mendekati tuntas (MT) dan kategori konsepsi SU akan disetarakan dengan kategori konsepsi tuntas (T).

Kriteria penilaian siswa di ambil berdasarkan kategorisasi jawaban berdasarkan pada setiap indikator:

Tabel 3. Menjelaskan Pengertian Senyawa Hidrokarbon Jawaban Siswa Skor Jawaban

\begin{tabular}{lllll} 
& $\mathbf{0}$ & $\mathbf{1}$ & $\mathbf{2}$ & $\mathbf{3}$ \\
\hline Menjawab salah, mengulang pertanyaan, jawaban tidak & 0 & & &
\end{tabular} ada, dan tidak relevan (asal-asalan)

Dapat menjawab salah satu dari komponen ini :

- Senyawa hidrokarbon adalah senyawa kimia organik

- Senyawa hidrokarbon unsur penyusunnya hanya unsur karbon dan hidrogen (salah satu unsurnya)

Dapat menjawab dua komponen ini : 2

- Senyawa hidrokarbon adalah senyawa kimia organik

- Senyawa hidrokarbon unsur penyusunnya hanya unsur karbon dan hidrogen (salah satu unsurnya)

Menjawab dengan benar semua komponen yang telah di 3 tentukan di bawah ini:

- Senyawa hidrokarbon adalah senyawa kimia organik

- Senyawa hidrokarbon unsur penyusunnya hanya unsur karbon dan hidrogen (salah satu unsurnya) 
Tabel 4. Mengelompokan Senyawa Hidrokarbon Berdasarkan Kejenuhan Ikatan

\begin{tabular}{|c|c|c|c|c|}
\hline \multirow[t]{2}{*}{ Jawaban Siswa } & \multicolumn{4}{|c|}{ Skor Jawaban } \\
\hline & 0 & 1 & 2 & 3 \\
\hline $\begin{array}{l}\text { Menjawab salah, mengulang pertanyaan, jawaban tidak } \\
\text { ada, dan tidak relevan (asal-asalan) }\end{array}$ & 0 & & & \\
\hline $\begin{array}{l}\text { Dapat menjawab salah satu dari komponen ini : } \\
\text { - Menerangkan ikatan jenuh dengan benar } \\
\text { - Menerangkan ikatan tak jenuh dengan benar } \\
\text { - Memberikan contoh ikatan jenuh dan tak jenuh } \\
\text { dengan benar }\end{array}$ & & 1 & & \\
\hline $\begin{array}{l}\text { Dapat menjawab dua komponen ini : } \\
\text { - Menerangkan ikatan jenuh dengan benar } \\
\text { - Menerangkan ikatan tak jenuh dengan benar } \\
\text { - Memberikan contoh ikatan jenuh dan tak jenuh } \\
\text { dengan benar }\end{array}$ & & & 2 & \\
\hline $\begin{array}{l}\text { Menjawab dengan benar semua komponen yang telah di } \\
\text { tentukan di bawah ini: } \\
\text { - Menerangkan ikatan jenuh dengan benar } \\
\text { - Menerangkan ikatan tak jenuh dengan benar } \\
\text { - Memberikan contoh ikatan jenuh dan tak jenuh } \\
\text { dengan benar }\end{array}$ & & & & 3 \\
\hline
\end{tabular}

Tabel 5. Memberikan Nama Senyawa Hidrokarbon Alkana, Alkuna, Alkena Jawaban Siswa Skor Jawaban

\begin{tabular}{lllll} 
& $\mathbf{0}$ & $\mathbf{1}$ & $\mathbf{2}$ & $\mathbf{3}$ \\
\hline Menjawab salah, mengulang pertanyaan, jawaban tidak ada, & 0 & & &
\end{tabular}
dan tidak relevan (asal-asalan)

Dapat menjawab salah satu dari komponen ini :

- Menunjukan rantai utama (alkana, alkena dan alkuna)

- Penomoran pada rantai utama (alkana, alkena dan alkuna)

- Pemberian nama alkil (alkana, alkena dan alkuna)

- Pemberian nama pada rantai utama (alkana, alkena dan alkuna)

Dapat menjawab dua komponen ini : 2

- Menunjukan rantai utama (alkana, alkena dan alkuna)

- Penomoran pada rantai utama (alkana, alkena dan alkuna)

- Pemberian nama alkil (alkana, alkena dan alkuna)

- Pemberian nama pada rantai utama (alkana, alkena dan alkuna)

Menjawab dengan benar semua komponen yang telah di

- Menunjukan rantai utama (alkana, alkena dan alkuna) 
- Penomoran pada rantai utama (alkana, alkena dan alkuna)

- Pemberian nama alkil (alkana, alkena dan alkuna)

- Pemberian nama pada rantai utama (alkana, alkena dan alkuna)

Tabel 6. Membedakan Atom C Primer, Sekunder, Tersier, Kuartener Jawaban Siswa Skor Jawaban

\begin{tabular}{|c|c|c|c|c|}
\hline & 0 & 1 & 2 & 3 \\
\hline $\begin{array}{l}\text { Menjawab salah, mengulang pertanyaan, jawaban tidak ada, } \\
\text { dan tidak relevan (asal-asalan) }\end{array}$ & 0 & & & \\
\hline $\begin{array}{l}\text { Dapat menjawab salah satu dari komponen ini : } \\
\text { - Menunjukan dengan benar salah satu atom C Primer, } \\
\text { Kuartener, Tersier dan Kuartener }\end{array}$ & & 1 & & \\
\hline $\begin{array}{l}\text { Dapat menjawab dua komponen ini : } \\
\text { - Menunjukan dengan benar salah satu atom C Primer, } \\
\text { Kuartener, Tersier dan Kuartener }\end{array}$ & & & 2 & \\
\hline $\begin{array}{l}\text { Menjawab dengan benar semua komponen yang telah di } \\
\text { tentukan di bawah ini: } \\
\text { - Menunjukan dengan benar salah satu atom C Primer, } \\
\text { Kuartener, Tersier dan Kuartener }\end{array}$ & & & & 3 \\
\hline
\end{tabular}

2. Jawaban siswa ditabulasi dalam masing-masing kategori konsepsi.

3. Dihitung persentase siswa pada masing-masing kategori konsepsi. Dengan rumus:

$$
N=\frac{\sum \text { jumlah siswa menjawab }}{\sum \text { total siswa }} \times 100 \%
$$

4. Dihitung rata-rata persentase konsepsi pada masing-masing indikator.

5. Setelah dilakukan analisis data, selanjutnya dilakukan wawancara untuk mengkonfirmasi jawaban siswa.

\section{Hasil Penelitian dan Pembahasan}

Hasil jawaban siswa kemudian diolah sebagai data konsepsi siswa. Butir soal pada tes uraian mewakili konsep-konsep pada materi senyawa hidrokarbon, 
dimana setiap butir soal memiliki kriteria penskoran. Total skor yang didapatkan siswa dikonversikan dalam bentuk persentase konsepsi dan kemudian diklasifikasikan kedalam tingkat konsepsi siswa. Konsepsi siswa pada materi senyawa hidrokarbon disajikan pada tabel 7.

Tabel 7 menunjukkan bahwa konsepsi siswa pada materi senyawa hidrokarbon dengan rata-rata persentase kategori tuntas sebesar 38,18\%. Konsepsi siswa ditelusuri dengan 4 indikator, dimana pada indikator satu untuk mengukur pengertian senyawa hidrokarbon, indikator 2 digunakan untuk menelusuri konsep perbedaan senyawa hidrokarbon berdasarkan kejenuhan ikatan. Indikator 3 digunakan untuk menelusuri konsep memberi nama senyawa hidrokarbon )alkana, alkena dan alkuna) dan indikator 4 digunakan untuk menelusuri konsep perbedaan atom $\mathrm{C}$ primer, sekunder, tersier dan kuartener.

Tabel 7.Persentase Siswa Pada Masing-Masing Kategori Konsepsi

\begin{tabular}{|c|c|c|c|c|c|}
\hline \multirow{2}{*}{\multicolumn{2}{|c|}{ Indikator }} & \multicolumn{4}{|c|}{ Kategori konsepsi } \\
\hline & & TM & TS & MT & $\mathbf{T}$ \\
\hline 1 & $\begin{array}{l}\text { Menjelaskan pengertian senyawa } \\
\text { hidrokarbon }\end{array}$ & 25 & 2,5 & 8,75 & 63,75 \\
\hline 2 & $\begin{array}{l}\text { Mengelompokan senyawa hidrokarbon } \\
\text { berdasarkan kejenuhan ikatan }\end{array}$ & 26,25 & 17,5 & 26,25 & 30 \\
\hline 3 & $\begin{array}{l}\text { Memberi nama senyawa hidrokarbon } \\
\text { (alkana, alkena, alkuna) }\end{array}$ & 34,6 & 25 & 14,58 & 25,83 \\
\hline & $\begin{array}{l}\text { Membedakan atom } \mathrm{C} \text { primer, sekunder, } \\
\text { tersier dan kuarterner }\end{array}$ & 30 & 18,75 & 18,125 & 33,125 \\
\hline
\end{tabular}

Besar konsepsi siswa dominan dapat dilihat pada grafik 1 . 


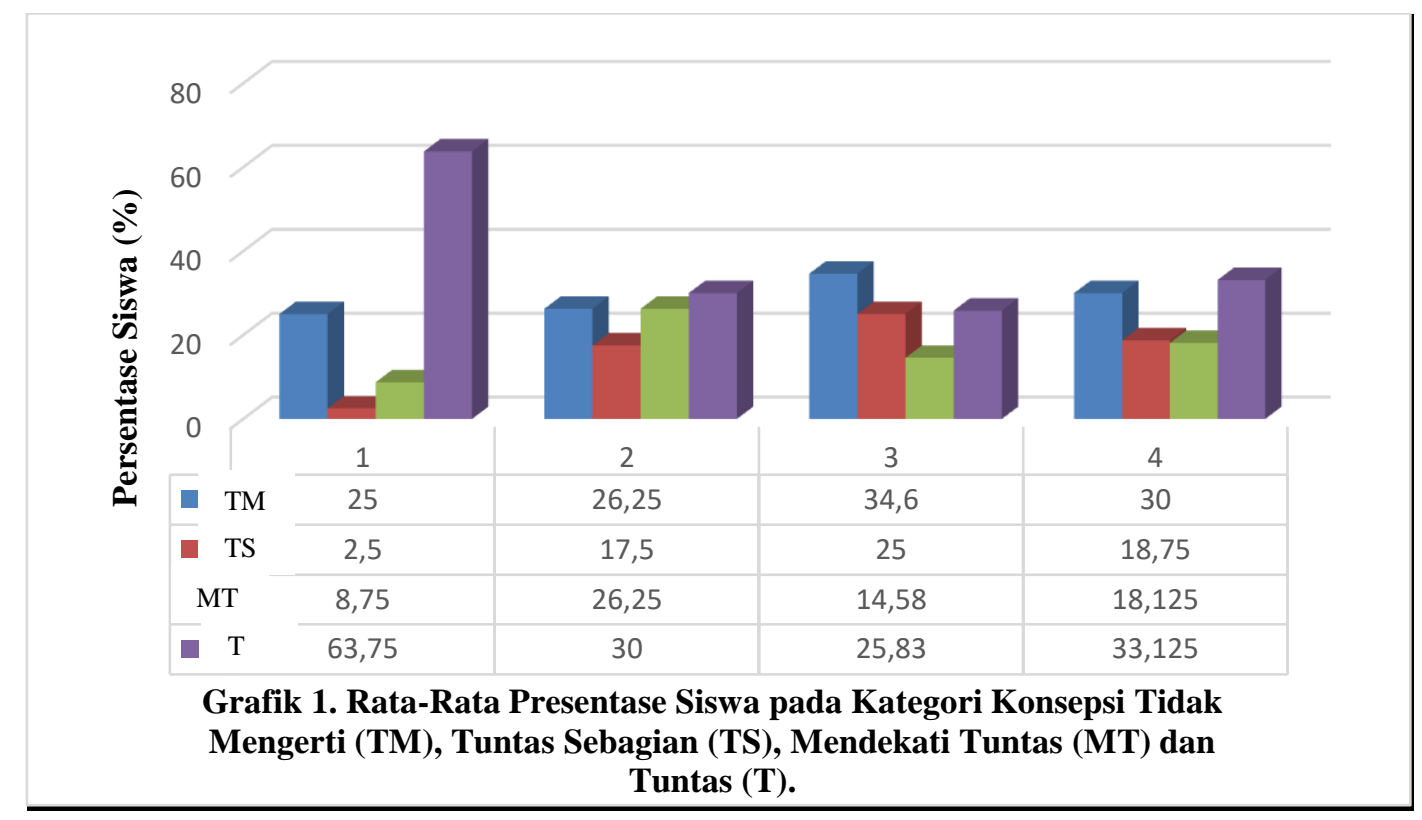

Grafik 1 menunjukkan bahwa konsepsi siswa pada indikator 1 telah memenuhi jawaban sesuai jawaban ilmiah sebesar 63,75\%. Indikator 2 dapat dilihat bahwa sebagian kecil siswa mampu menjawab berdasarkan konsep ilmiah sebesar $30 \%$. Indikator 3 dapat dilihat bahwa hanya sebagian kecil saja yang ammpu menjawab dengan konsep ilmiah sebesar 25,83\%. Indikator 4 dapat dilihat bahwa siswa yang memenuhi sesuai konsep ilmiah jauh lebih banyak dibandingkan dengan indikator 2 dan indikator 3 sebesar 33,125\%.

\section{Deskripsi Konsepsi Siswa Tentang Pengertian Senyawa Hidrokarbon}

Konsepsi ini ditelusuri melalui butir soal nomor 1.

1. Apa yang dimaksud dengan senyawa hidrokarbon. Jelaskan!

Butir soal nomor 1 pada tes essay, digunakan untuk mencapai tujuan menjelaskan pengertian senyawa hidrokarbon. Hasil analisis jawaban siswa menunjukan dengan tuntas (T) $63,75 \%$ siswa telah mampu menjawab bahwa senyawa hidrokarbon adalah senyawa organik yang tersusun atas hidrogen dan karbon. Sebanyak 25\% siswa tidak mampu menjawab dengan benar pengertian dari senyawa hidrokarbon dengan jawaban senyawa hidrokarbon dibedakan menjadi 
alkana, alkuna dan alkena. Siswa sebanyak 25\% masuk kategori tidak mengerti (TM). 2,5\% siswa siswa mampu menjawab pengertian senyawa hidrokarbon dan masih ada satu komponen saja yang benar tetapi komponen lainnya masih salah,dominannya siswa hanya mampu menjawab komponen senyawa hidrokarbon yang terdiri dari unsur penyusunnya hanya karbon, maka siswa sebanyak 2,5\% masuk kategori tuntas sebagian (TS) dan 8,75\% siswa menjawab mendekati tuntas (MT) dikarenakan siswa mampu menjawab beberapa komponen pengertian senyawa hidrokarbon seperti siswa mampu menjawab penyusun senyawa hidrokarbon dengan benar tetapi siswa belum memahami senyawa hidrokarbon adalah senyawa organik.

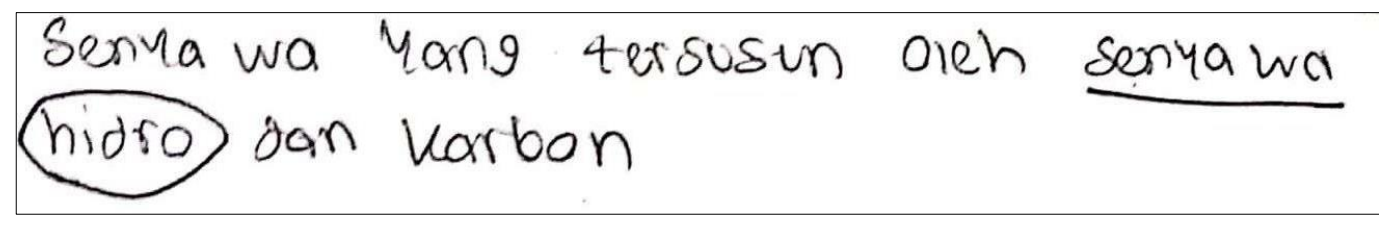

\section{Gambar 1. Jawaban Siswa (S38) tentang Pengertian Senyawa Hidrokarbon}

Berdasarkan pola jawaban, konsepsi siswa tentang pengertian senyawa hidrokarbon yang tersusun atas senyawa hidro dan karbon. Dari jawaban tersebut siswa tidak dapat mendeskripsikan secara jelas komponen apa saja yang ada dalam senyawa hidrokarbon. Wawancara dilakukan untuk mengkonfirmasi kembali jawaban siswa.

Berdasarkan hasil wawancara, disimpulkan bahwa siswa tidak memiliki konsep yang utuh tentang hidrokarbon, sehingga tidak dapat menjelaskan senyawa hidrokarbon sebagai senyawa organik yang terdiri dari unsur karbon dan hidrogen. Siswa juga tidak mampu menjelaskan bahwa hidrogen adalah senyawa organik. 


\section{Deskripsi Konsepsi Siswa Tentang Membedakan Senyawa Hidrokarbon \\ Berdasarkan Kejenuhan Ikatan}

Indikator ini diwakili oleh butir soal nomor 2 untuk mengetahui konsepsi siswa tentang perbedaan senyawa hidrokarbon berdasarkan kejenuhan ikatannyapada soal tes essay.

2. Jelaskan perbedaan ikatan jenuh dan ikatan tak jenuh pada senyawa hidrokarbon beserta masing-masing contohnya!

Butir soal nomor 2, digunakan untuk mencapai tujuan menjelaskan perbedaan ikatan jenuh dan ikatan tak jenuh senyawa hidrokarbon. Dari jawaban siswa, terdapat $26,25 \%$ siswa yang masuk dalam kategori tidak mengerti (TM) siswa salah mengerti bahwa ikatan jenuh merupakan ikatan senyawa yang sudah penuh atau terpenuhi dan ikatan tak jenuh adalah senyawa yang memiliki ruang yang masih kosong untuk bisa menerima atom-atom lainnya.Terdapat 17,5\% siswa yang masuk dalam kategori memiliki konsep tuntas sebagian (TS) karena siswa hanya menjawab contoh dari senyawa hidrokarbon ikatan jenuh adalah alkana dan senyawa hidrokarbon ikatan tak jenuh adalah alkena dan alkuna, sedangkan siswa tidak menyebutkan apa perbedaan dari ikatan jenuh dan ikatan tak jenuh senyawa hidrokarbon. Terdapat sebanyak 26,25\% siswa mendekati tuntas (MT) siswa menjawab beberapa komponen yang benar bahwa senyawa hidrokarbon ikatan jenuh adalah ikatannya tunggal dan contohnya adalah alkana, sedangkan ikatan tak jenuh adalah ikatan senyawanya berikatan dengan atom lainnya dan contohnya alkena dan alkuna. 30\% siswa masuk kedalam kategori Tuntas (T) menjawab sesuai konsep ilmiah. Jawaban siswa yang masuk dalam kategori TS dapat dilihat pada gambar 2 berikut: 


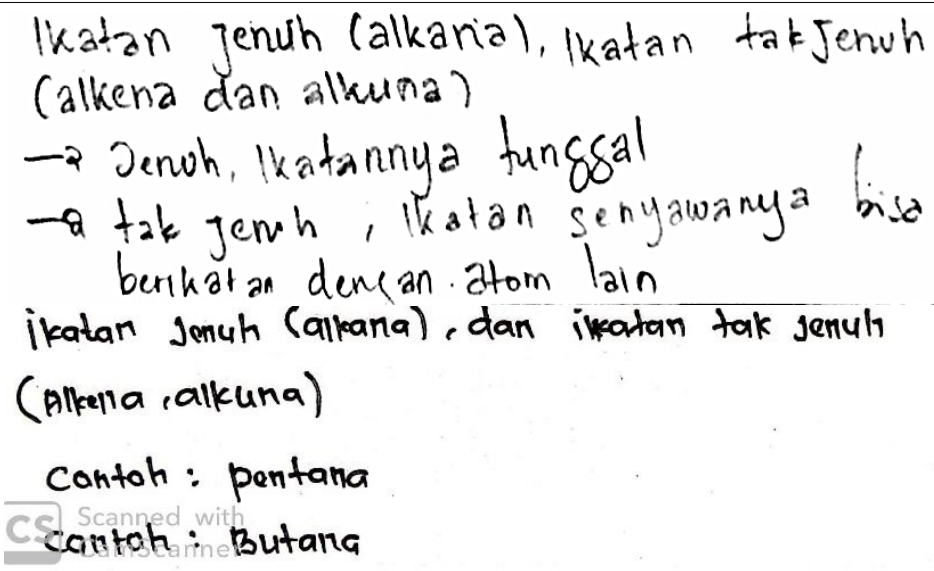

Gambar 2. Jawaban Siswa (S6) dan (S5) tentang Perbedaan Ikatan Jenuh dan Ikatan Tak Jenuh Senyawa Hidrokarbon

Pola jawaban yang terlihat pada gambar 16 menunjukan, siswa

menganggap bahwa alkana adalah ikatan jenuh sedangkan alkena dan alkuna adalah ikatan tak jenuh. Wawancara dilakukan untuk mengkonfirmasi jawaban siswa.

Berdasarkan hasil wawancara yang dilakukan, siswa S6 menjelaskan bahwa siswa dapat menjawab karna telah membaca materi hidrokarbon, dan siswa menyebutkan bahwa perbedaan ikatan jenuh dan ikatan jenuh hanya pada berdasarkan apa yang pernah diingat oleh siswa. Siswa S6 juga menyebutkan pada jawaban bahwa contoh dari pentana dan butana adalah contoh dari ikatan jenuh dan tak jenuh. Pentana dan butana termasuk kedalam senyawa hidrokarbon alifalik jenuh yaitu alkana. Sedangkan siswa S5 dapat menjelaskan bahwa ikatan jenuh adalah ikatan tunggal dan ikatan tak jenuh ikatan yang bias berikatan dengan atom lainnya. Atom lainnya yang siswa S5 maksudkan adalah metil, sedangkan kita mengetahui di materi kimia kelas $\mathrm{X}$ bahwa metil adalah alkil hidrokarbon. Disimpulkan dari jawaban siswa S6 dan siswa S5 tidak memahami konsep alkil dan tidak dapat membedakan tata nama senyawa alkana, alkena dan alkuna. 


\section{Deskripsi Konsepsi Memberi Nama Senyawa Hidrokarbon Alkana, Alkena,}

\section{Alkuna}

\section{Memberi Nama Senyawa Alkana}

Indikator 3 digunakan untuk mengetahui konsepsi siswa tentang pemberian tata nama senyawa hidrokarbon. Pada indikator ini akan diungkap dengan menggunakan soal nomor 3 bagian A. Dari analisis yang dilakukan secara dominan siswa pada kategori tidak mengerti (TM) dengan besar persentase $34,6 \%$.

Berilah nama IUPAC senyawa-senyawa berikut!

a.<smiles>CC(C)C(C)(C)C</smiles>

Soal nomor 3 bagian A, siswa diminta untuk memberikan nama IUPAC pada senyawa alkana. Hasil jawaban soal nomor 3 bagian a menunjukan 36,25\% siswa masuk dalam kategori (TM) jawaban siswa tidak dapat dipahami atau jawaban salah, (TS) 43,75\% siswa menjawab dengan benar hanya satu bagian komponen saja, (MT) 3,75\% siswa menjawab dengan benar beberapa komponen konsepsi ilmiahnya, dan 16,25 siswa masuk kedalam kategori $\mathrm{T}$ menjawab dengan benar. Hasil tersebut menunjukan bahwa hanya $16,25 \%$ siswa saja yang mampu menjawab dengan tuntas dan banyak siswa menjawab tetapi hanya tuntas sebagian saja. Pada kategori TS terdapat jawaban siswa yang akan di tunjukan pada gambar 17 


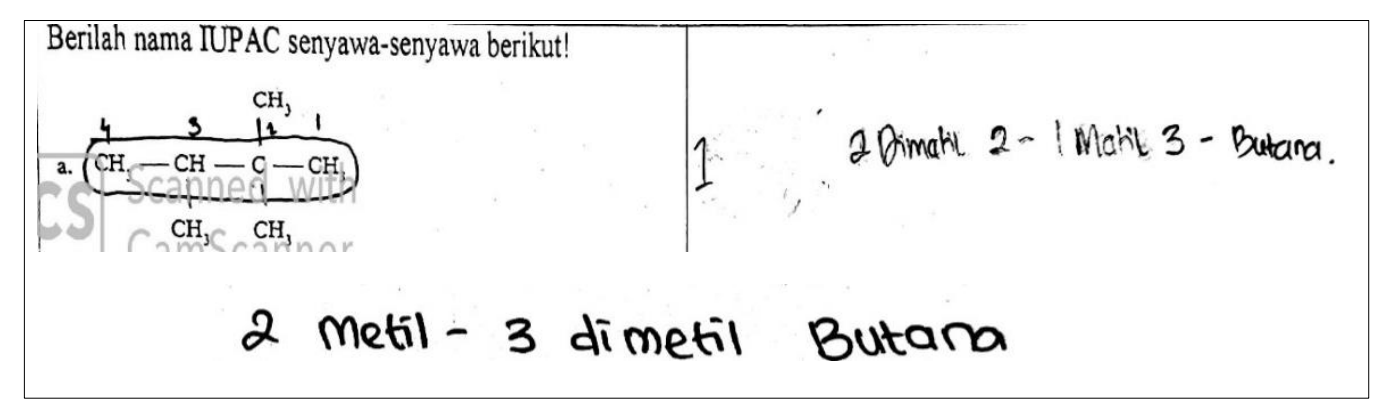

Gambar 3. Jawaban Siswa (S33) dan (S40) tentang Pemberian Tata

\section{Nama Senyawa Alkana}

Berdasarkan gambar 3 menunjukan siswa S33 mampu menunjukanrantai utama atau rantai induk dan mampu menunjukan nomor pada rantai induk pada senyawa alkana. Jawaban siswa S33 dapat dilihat masih ada kesalahan dalam memberi nama IUPAC pada senyawa alkana. Jawaban siswa S40 tidak telihat menunjukan mana yang rantai utama dan nomor pada rantai utamanya. Siswa S40 juga masih belum ada kesalahan dalam memberikan nama pada senyawa alkana. Wawancara dilakukan untuk konfirmasi jawaban siswa.

Hasil wawancara yang dilakukan menjelaskan bahwa siswa sudah mengerti mengenai rantai induk atau rantai utama dan memberikan penomoran pada rantai utama. Siswa masih belum sepenuhnya memahami memberikan nama pada senyawa alkana, sehingga siswa memberikan nama IUPAC pada senyawa alkana menggunakan logika atau panalaran saja.

\section{Memberi Nama Senyawa Alkena}

Konsepsi indikator ini dijaring dengan butir soal nomor 3 bagian B digunakan untuk mengungkap konsepsi siswa tentang pemberian nama senyawa alkena. Hasil analisis, secara dominan siswa berada pada kategori TM dan MT dengan besar persentase $33,75 \%$. 
Berilah nama IUPAC senyawa-senyawa berikut!

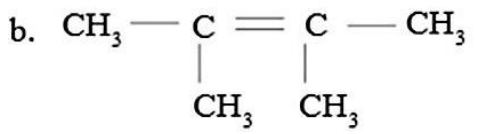

Pada butir soal nomor 3 bagian B berisikan soal tentang pemberian nama IUPAC pada senyawa alkena. Dari soal yang diberikan, diketahui $15 \%$ siswa kategori TS dan $17,5 \%$ masuk dalam kategori T. Hasil ini menunjukan bahwa masih banyak siswa belum memahami pemberian nama pada senyawa alkena dan hasil yang sama banyak juga siswa mampu menjawab mendekati tuntas dalam pemberian nama senyawa alkena. Jawaban siswa pada kategori TS disajikan pada gambar 4 berikut:

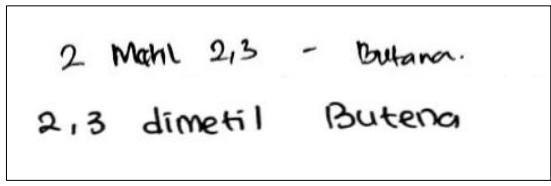

Gambar 4. Jawaban Siswa tentang Pemberian Nama Senyawa Alkena Jawaban siswa menunjukan siswa tidak memahami dalam memberi nama pada senyawa alkena. Ketidak pahaman ini membuat siswa mengalami kesalahan dalam memberikan nama senyawa alkena. Wawancara dilakukan untuk konfirmasi jawaban siswa.

Hasil wawancara yang dilakukan menunjukan, siswa (S33) dapat menunjukan rantai utama dan dapat memberikan penomoran pada rantai utama dengan benar. Siswa (S33) tidak memahami dalam memberi nama senyawa, dan tidak paham tata nama alkena. Ketidak pahaman ini dapat dilihat dari penjelasan siswa (S33) pada wawancara dalam hal penamaan alkil yang benar dan pemberian nama yang benar pada senyawa alkena. Siswa (S40) sudah memahami dalam tata nama senyawa alkena hanya saja masih kurang di pemberian nomor tata nama senyawa alkenanya. 


\section{Memberi Nama Senyawa Alkuna}

Indikator 3 pada soal nomor 3 bagian $\mathrm{C}$ ini digunakan untuk mengungkap konsepsi siswa tentang pemberian nama senyawa alkuna. Hasil analisis jawaban siswa, diketahui dominan siswa pada kategori tuntas (T) sebesar 43,75\%.

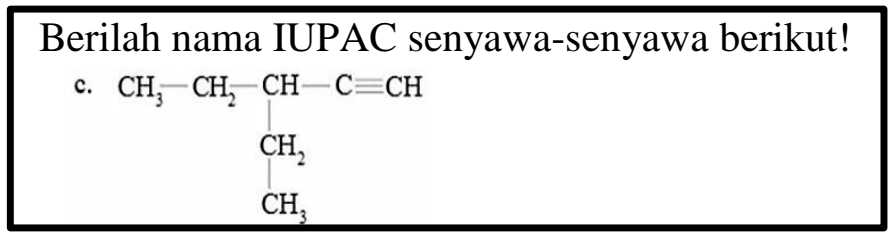

Pada soal nomor 3 bagian $\mathrm{C}$, diberikan untuk mengetahui konsepsi siswa dalam pemberian nama senyawa alkuna. Jawaban siswa menunjukan 33,75\% masuk dalam kategori TT, sebanyak 16,25\% siswa masuk dalam kategori TS dan 6,25\% siswa masuk kategori MT. Jawaban pada kategori T dan TS disajikan pada gambar 5

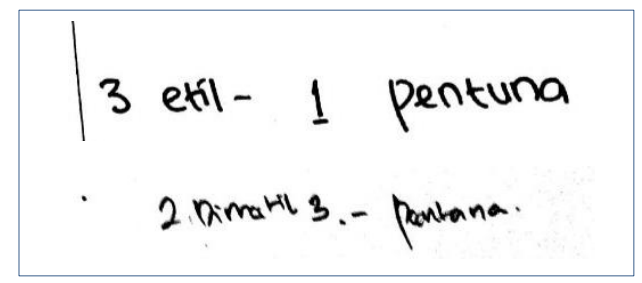

Gambar 5. Jawaban Siswa Tentang Pemberian Nama Senyawa Alkuna

Hasil wawancara menjelaskan bahwa siswa (S21) memiliki konsepsi yang benar dan tepat pada pemberian nama pada alkuna. Ketika siswa ditanya penjelasan mengenai jawabannya tersebut dengan mudahnya siswa dapat menjelaskan serta menunjukan alasannya dalam menjawab. Siswa (S33) masih saja sama seperti di pemberian tata nama senyawa alkana dan alkuna sampai pada pemberian tata nama senyawa alkuna alasan nya pun hampir sama. Karena siswa tidak memahami atau salah mengerti mengenai pemberian nama senyawa hidrokarbon maka jawaban dan alasannya pun tetap salah. 


\section{Deskripsi Konsepsi Siswa Tentang Perbedaan Atom C Primer, Sekunder,}

\section{Tersier dan Kuartener}

Indikator 4 digunakan untuk mengetahui konsepsi siswa tentang membedakan atom $\mathrm{C}$ primer, sekunder, tersier dan kuartener. Indikator ini menggunakan 1 soal yaitu nomor 4 . Ada soal nomor 4 bagian A dan soal nomor 4 bagian $\mathrm{B}$.

Hitunglah jumlah atom $\mathrm{C}$ primer, $\mathrm{C}$ sekunder, $\mathrm{C}$ tersier, dan $\mathrm{C}$ kuarterner pada masing-masing senyawa hidrokarbon berikut!

a. $\mathrm{CH}_{3}-\mathrm{CH}_{2}-\underset{\mathrm{CH}_{3}}{\mathrm{CH}}-\left.\right|_{\mathrm{CH}_{3}} ^{\mathrm{CH}}-\mathrm{CH}-\mathrm{CH}_{3}$

b<smiles>CC(C)CC(C)(C)C</smiles>

Butir soal nomor 4 bagian a dan bagian b, digunakan untuk mencapai tujuan membedakan atom $\mathrm{C}$ primer, sekunder, tersier dan kuartener. Dari jawaban siswa yang masuk dalam kategori memiliki konsep tuntas (T) sebanyak 33,125\%. Jawaban siswa yang masuk dalam kategori TS dan T dapat dilihat pada gambar 6 berikut:

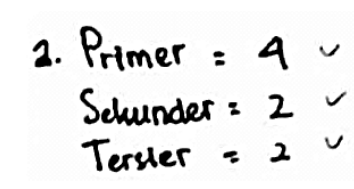

b. Primer $=5$ Selunder $=1 \vee$ Tersier $=12$
huarterner $=1$

Gambar 6. Jawaban Siswa (S5) tentang Membedakan Atom C Primer, Sekunder, Tersier dan Kuartener kategoriT 
Pola jawaban yang terlihat pada gambar 22 menunjukan, siswa mampu memberikan jawaban yang tepat dan benar sesuai dengan konsep ilmiah. Wawancara dilakukan untuk mengkonfirmasi jawaban siswa.

Hasil wawancara membenarkan bahwa konsepsi siswa (S5) memahami secara mendasar dan secara ilmiah mengenai membedakan atom $\mathrm{C}$ primer, sekunder, tersier dan kuartener. Jawaban siswa kategori TS terlihat pada gambar 7 berikut:

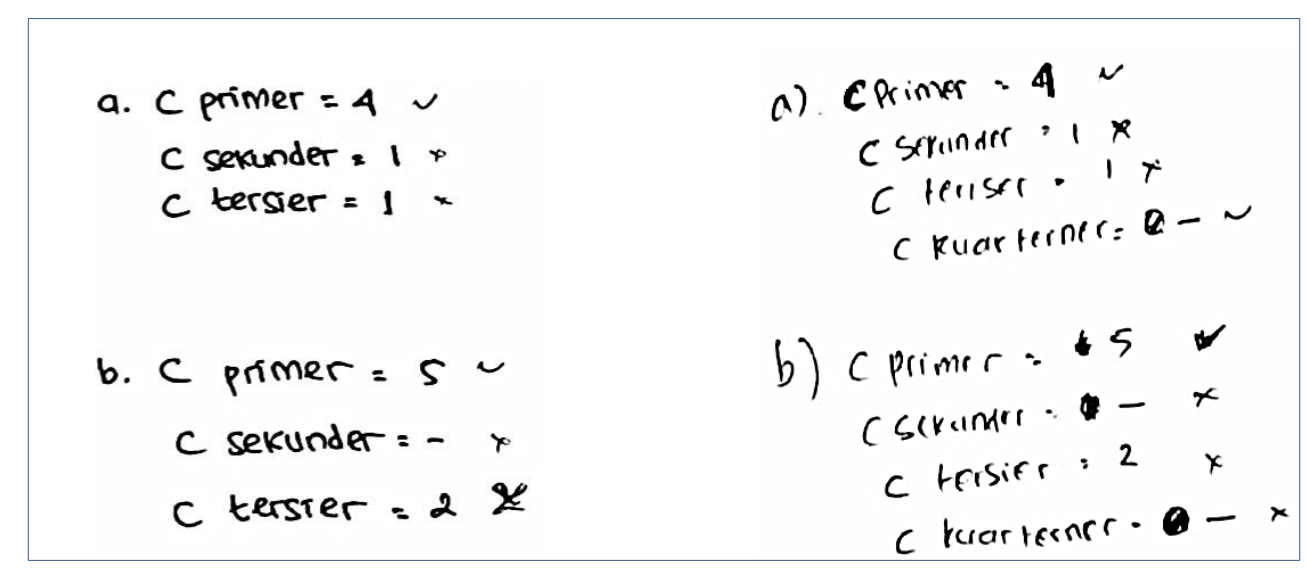

\section{Gambar 7. Jawaban Siswa tentang Membedakan Atom C Primer, Sekunder, Tersier dan Kuartener kategoti TS.}

Jawaban siswa yang dapat dilihat menunjukan bahwa siswa sepertinya masih belum memahami mengenai apa itu atom $\mathrm{C}$ primer, sekunder, tersier dan kuartener. Wawancara dilakukan untuk konfirmasi jawaban siswa.

Wawancara yang dilakukan memperlihatkan bahwa siswa memang dapat menjawab tapi masih belum memahami konsep dari atom $\mathrm{C}$ primer, sekunder, tersier dan kuartener. Hasil analisis yang dilakukan terhadap jawaban siswa menunjukan $30 \%$ siswa tidak tuntas dalam menjawab soal nomor 4 , sebanyak $18,75 \%$ siswa masuk kategori tuntas sebagian, 18,125\% siswa masuk kategori mendekati tuntas dan $33,125 \%$ siswa dapat menjawab dengan tuntas atau sesuai dengan konsep ilmiah. 
Recka Susanti (341-359)

\section{Kesimpulan}

Berdasarkan hasil penelitian dan pembahasan dapat disimpulkan bahwa:

1. Konsepsi siswa tentang pengertian senyawa hidrokarbon adalah sebagai senyawa organik yang terdiri dari unsur karbon dan unsur hidrogen. Jumlah siswa yang konsepsinya benar tentang pengertian senyawa hidrokarbon adalah $63,75 \%$.

2. Konsepsi siswa tentang membedakan atom $\mathrm{C}$ primer, sekunder, tersier dan kuartener adalah atom $\mathrm{C}$ primer hanya mengikat satu atom $\mathrm{C}$ lainnya, atom $\mathrm{C}$ sekunder mengikat dua atom $\mathrm{C}$ lainnya, atom $\mathrm{C}$ tersier mengikat tiga atom C lainnya dan atom $\mathrm{C}$ kuartener mengikat empat atom $\mathrm{C}$ lainnya.Jumlah siswa yang konsepsinya benar tentang membedakan atom $\mathrm{C}$ primer, sekunder, tersier dan kuartener adalah $33,125 \%$.

3. Konsepsi siswa tentang perbedaan hidrokarbon ikatan jenuh dan ikatan tak jenuh adalah ikatan jenuh hanya memiliki ikatan tunggal sedangkan ikatan tak jenuh setidaknya memiliki ikatan rangkap dua atau ikatan rangkap tiga. Jumlah siswa yang belum memahami tentang perbedaan senyawa hidrokarbon ikatan jenuh dan senyawa hidrokarbon ikatan tak jenuh adalah $26,25 \%$.

4. Konsepsi siswa tentang pemberian nama senyawa alkana yang belum memahami tentang memberikan nama senyawa hidrokarbon alkana, alkena dan alkuna adalah $30 \%$.

\section{Saran}

Berdasarkan kesimpulan hasil penelitian, maka saran yang diajukan penulis adalah sebagai berikut: 
1. Perlu dilakukan penelitian lanjutan mengenai konsep perbedaan senyawa hidrokarbon ikatan jenuh dan senyawa hidrokarbon ikatan tak jenuh dan konsep pemberian nama senyawa hidrokarbon alkana, alkena dan alkuna.

2. Pembelajaran kimia khususnya tentang konsep perbedaan senyawa hidrokarbon ikatan jenuh dan senyawa hidrokarbon ikatan tak jenuh dan konsep pemberian nama senyawa hidrokarbon alkana, alkena dan alkuna perlu di perhatikan proses pembelajaran yang jauh lebih terarah oleh pengajar atau guru.

\section{Daftar Pustaka}

Abraham, M.R., Williamson, V.M., \& Westbrook, S.L. (1994). A cross-age study of the understanding of five chemistry concept. Journal of Research in Science Teaching, 31, 147-165.

Calik, M., \& Ayas, A. (2005). A Cross-Age Study on The Understanding of Chemical Solution and Their Components. International Education Journal. 6, (1), hlm. 30-41.

Dahromi, Umi. (2016). Konsepsi Mahasiswa Pendidikan Kimia Tentang Kenaikan Titik Didih Larutan. Skripsi, tidak diternitkan, Universitas Palangka Raya.

Dahar, R. W. (1991). Teori-Teori Belajar. Jakarta: Erlangga

Depdikbud. (1999). Kamus Besar Bahasa Indonesia. Jakarta : Balai Pustaka

Morgil, Inci dan Yoruk, Nuray. (2006). Cross-Age Study Of The Understanding Of Some Concept In Chemistry Subjects In Science Curiculum. Journal of Turkish Science Education 3 (1). 